\title{
Land application of sewage sludge in China
}

\author{
Min-Jian Wang \\ Research Centre for Eco-Environmental Sciences, Chinese Academy of Sciences, PO Box 287I, \\ Beijing 100085, People's Republic of China
}

Received 10 October 1996; accepted 14 December 1996

\begin{abstract}
Land application of sewage sludge in China is thoroughly reviewed. Operation of sewage sludge disposal is usually expensive and/or easy to contaminate the environment. In China, most sewage sludge has not been treated and disposed of properly, resulting in environmental pollution and potential exposure to humans. In the near future, sewage sludge production in China will increase rapidly together with the dramatic increase of municipal wastewater treatment ratio (treated/produced), implying that the problem of sewage sludge disposal will become more serious and unavoidable. Proper land utilization of stabilized sewage sludge can make a positive contribution to agriculture, forestry, horticulture and city development. Heavy metals, organic pollutants and pathogens concentrated in sewage sludge during wastewater treatment are the main obstacles to land application of sewage sludge. To promote land application of sewage sludge in China, a statewide survey of sewage sludge production and harmful components in sewage sludge should be carried out. Sewage sludge management and technologies for sludge treatment and disposal suitable to Chinese conditions should be paid more attention. (C) 1997 Elsevier Science B.V.
\end{abstract}

Keywords: Sewage sludge; Land application; Waste disposal; Pollution control; Agriculture

\section{Background}

Sewage sludge is an unwanted and inevitable by-product of wastewater treatment process. Sedimentation both before and after wastewater biotreatment produces sewage sludge. More and more wastewater is produced along with developing industry and agriculture and in improving human life. On the other hand, people are concerned about environmental protection more than ever and relative legislation and regulation are becoming more critical [1]. The amount of wastewater treated and therefore the sewage sludge produced will increase rapidly. It is estimated that China is now producing more than 20 billion $\mathrm{m}^{3}$ of municipal wastewater per annual, about $7 \%$ of which, i.e. 1.4 billion $\mathrm{m}^{3}$, is treated in sewage treatment plants, producing some 0.4 million tons (dry weight) of sewage sludge. However, only one third of these wastewater treatment 
plants possess sewage sludge stabilization equipment; less than one tenth of the plants are equipped with full process for sewage sludge treatment and disposal. Sewage sludge treatment and disposal have seriously challenged the development of the wastewater treatment industry and environmental protection in China. Furthermore, according to national planning, the municipal wastewater treatment rate in China will be increased to $20-30 \%$ by the end of this century and to $40-50 \%$ in 2010 , indicating that a dramatic increase of sewage sludge production will occur in this country very soon [2]. It is obvious that China has to treat and dispose of it's rapidly increasing amount of sewage sludge.

Sludge disposal is an expensive operation and could result in new environmental pollution if dealt with improperly $[3,4]$. In the $1980 \mathrm{~s}$, for example, about $\$ 844$ million had to be paid to dispose of 7.0 million tons (dry weight) of sewage sludge in the US each year and some $£ 250$ million for 1.2 million tons (dry weight) in the UK, i.e. the average cost was approximately $\$ 121$ per ton and $£ 208$ per ton, respectively $[5,6]$. However, even in developed countries like these, sewage sludge disposal options still need improving, e.g. banning the operation of dumping into the sea which causes pollution and encouraging beneficial use $[3,7]$. Nevertheless, it would be very difficult for a developing country like China to pay so much for sludge disposal, which means that both environmentally and economically desirable options have to be developed and adopted.

\section{Sewage sludge disposal}

The main problem faced by the wastewater treatment industry in China is the lack of financial support, which causes the difficulty in sewage sludge treatment and disposal. There has been no statewide survey for the quantitative data of sewage sludge production and disposal. However, there are at least three methods currently being used in China, as follows:

\subsection{Dumping into the cheironment}

A substantial portion of the sewage sludge (generally untreated) has been dumped into the environment, mainly the surface water body or field which has resulted in a serious environmental pollution problem in some urban and suburban areas. Sewage sludge in the field emits odors causing air pollution. Pathogens in sludge are of potential harm to humans. Organic matter and harmful chemicals in sewage sludge contaminate the surface and ground water systems; dumping sewage sludge into the environment carelessly simply counteracts efforts to treat wastewater. This operation should be stopped and is now being replaced by improved techniques in China although it was thought to be one of the "cheapest' and 'simplest' options.

\subsection{Landfilling}

Some sewage sludge is collected, transported and disposed with municipal solid waste, increasing the load of solid waste treatment in cities. For example, with a treatment capability of 200000 tons of wastewater per day, the Sibao sewage treatment plant in Hangzhou of Zhejiang Province once paid about RMB $¥ 0.3$ million per annual for sludge landfill as municipal solid waste [8]. Guangzhou Datansha wastewater treatment plant also landfilled its sewage sludge at a remote suburban area [9]. Because most of municipal solid waste has not been treated and disposed of properly in China, this portion of sewage sludge, in many cases, is dumped into the environment. Even when treated and buried in well designed landfills, this is still not an environmentally fricndly method, resulting in the waste of the useful components in sewage sludge. According to the principles of resource conservation and environmental protection, this operation should be replaced by a beneficial use.

\subsection{Incineration}

Some sewage sludge produced from wastewater treatment plants receiving some industrial wastewater containing toxic chemicals is dewa- 
Table 1

Average content of nutrients in China's sewage sludges

\begin{tabular}{|c|c|c|c|c|c|}
\hline Sewage treatment plant & $N(1 / 1)$ & $P(\%)$ & $\mathrm{K}(\%)$ & $\mathrm{Ca}(1 / 1)$ & Organic matter $(1 / 1)$ \\
\hline Guangzhou Datansha [9,11] & 1.80 & 2.24 & 1.49 & $\cdots$ & 31.7 \\
\hline Suzhou Chengxi $[12,1,3]$ & 4.65 & 1.22 & 0.44 & & 34.30 \\
\hline$X i a n[14-16]$ & 1.81 & 1.49 & 1.57 & 7.17 & 28.23 \\
\hline Taiyuan Yangjiabao [17] & 1.42 & 0.47 & 0.34 & - & 28.06 \\
\hline Taiyuan Beijiao [17] & 2.76 & 1.04 & 0.49 & - & 40.31 \\
\hline Taiyuan Yinjiabao [17] & 1.89 & 1.06 & 0.35 & -- & 30.45 \\
\hline Taiyuan Gujiao [17] & 0.782 & 0.223 & 0.61 & $\ldots$ & 9.20 \\
\hline Taiyuan Zhenchengdi [17] & 0.246 & 1.25 & 0.43 & - & \\
\hline Hangzhou Sibao [8] & 1.10 & 1.15 & 0.74 & $\cdots-$ & 31.8 \\
\hline Jinshan Shihua $[8]$ & 7.5 & 1.5 & -- & -- & \\
\hline Beijing Jiuxianqiao $[18,19]$ & 3.15 & 0.641 & 0.39 & -- & 62.0 \\
\hline Beijing Gaobeidian $[16,19]$ & 3.31 & 0.275 & 1.26 & -- & 35.7 \\
\hline Median & 1.85 & 1.11 & 0.49 &.-- & 31.75 \\
\hline Mean \pm S.D. & $2.53 \pm 1.98$ & $1.05 \pm 0.58$ & $0.74 \pm 0.47$ & -- & $33.18 \pm 13.02$ \\
\hline
\end{tabular}

Unavailable data is represented by ${ }^{\circ}$

tered and combusted in incinerators. For example, the Jilin wastewater treatment plant once incinerated its sludge - an expensive method of sewage disposal. Both the investment and operation are costly. Recovering the energy by power generation and/or providing heat may reduce the cost of sludge combustion in large plants. With conventional equipment, this operation has high potential to contaminate the environment by creating and spreading some highly toxic chemicals such as PCDDs and PCDFs. Once the USEPA analyses indicated that incineration poses more carcinogenic risk than do other uses or disposal methods [10]. Improving the combustion process is the main way to prevent environmental pollution. However, controlling wastewater quality may also be an eventual solution.

Although the methods described above account for a large proportion of the sewage sludge disposal, beneficial use is now attracting more and more attention for waste treatment and disposal in China.

\section{Land application of sewage sludge}

Effort has been made to use sewage sludge beneficially in many ways in China. Sludge has been digested creating gas for power generation, heating and chemical industry. In the construction industry, sewage sludge has been used to make bricks and other building materials. These options save resources of energy and agricultural soil while disposing sewage sludge. However, considering low cost and high efficiency, one of the most attractive and beneficial options for sludge use in China may still be land application.

Sewage sludge usually contains high proportions of organic matter and plant nutrients. Tables 1 and 2 give the nutritious chemical contents of sewage sludge in China and some other countries (UK, USA and South Africa) respectively $[11-21]$. The average content of organic matter in sewage sludges from 12 wastewater treatment plants in seven Chinese cities (Fig. 1) is about $33.18 \pm 13.02 \%$, with a median of $31.75 \%$, which is lower than sludges produced in some developed countries $(40-80 \%)$ [22]. The main nutrients, i.e. nitrogen, phosphorus and potassium, are some $2.53,1.05$ and $0.74 \%$ in these sewage sludges, respectively, slightly lower than those in the other countries listed in Table 2 with the exception of potassium. Besides the three main nutrients, sludge can also supply many other micro-nutrient elements [23--27]. 
Table ?

Nutrients in sewage sludges in some other countries

\begin{tabular}{|c|c|c|c|c|c|c|c|c|c|c|}
\hline & \multicolumn{2}{|c|}{ UK $[20]$} & \multicolumn{2}{|c|}{ US [20] } & \multicolumn{4}{|c|}{$\operatorname{RS} \wedge[21]$} & \multirow[t]{2}{*}{ Median } & \multirow[t]{2}{*}{ Mean \pm S.D } \\
\hline & 1 & 2 & 1 & 2 & 1 & 2 & 3 & 4 & & \\
\hline$N$ & -- & $\ldots$ & - & $\cdots \cdots$ & 2.1 & 3.4 & 2.9 & 2.8 & 2.9 & $2.8 \pm 0.5$ \\
\hline$P$ & 1.5 & 1.7 & 1.6 & 3.0 & 0.9 & 1.7 & 1.6 & 1.1 & 1.6 & $1.6 \pm 0.6$ \\
\hline $\mathrm{K}$ & 0.2 & 0.2 & 0.7 & 0.3 & 0.2 & 0.2 & 0.2 & 0.2 & 0.2 & $0.3 \pm 0.2$ \\
\hline $\mathrm{Ca}$ & - & 5.5 & 2.5 & 4.9 & 3.4 & 3.0 & 2.2 & 2.9 & 3.0 & $3.5 \pm 1.2$ \\
\hline $\mathrm{Mg}$ & $\ldots$ & 0.3 & 0.6 & 0.5 & - & - & - & $\ldots$ & 0.5 & $0.5 \pm 0.2$ \\
\hline
\end{tabular}

'-..' represents unavailable data.

The traditional Chinese way to dispose of organic wastes is by land application, serving agriculture which has played a very important role in China's economics. Organic wastes have been composed and applied to agricultural fields as fertilizer and soil conditioner for thousands of years. Organic matter, nitrogen and phosphorus content in sewage sludge are five, three and three times those in manure (a typical traditional organic waste used for agricultural land in China) respectively, attracting farmers' interesting [17]. Being rich in organic matter and plant nutrients, a certain portion of China's sewage sludge has been utilized in a similar way to other traditional organic waste. Land use has been carried out especially for sewage sludge from some wastewater treatment plants in large cities such as Beijing, Tianjin and Shanghai for more than 20 years [8]. In some areas, sludge land use has a history as old as 30 years [28]. In most cases, sewage sludge is dewatered and then applied directly to land without stabilization treatment. A portion of the sludge is even utilized without any treatment including the dewatering process [13,17]. Surface application has been the most commonly used technique for sewage sludge land utilization.

Raw sewage sludge almost always contains a large number of pathogens such as bacteria, viruses, protozoa and parasitic worms, and is usually vector attractive, which may threaten human health [29]. However, anaerobic digestion, a widely used technology in developed countries, is not adopted by most wastewater treatment plants of small or medium scale in China because of the high cost of the equipment and operation which may be reduced by energy recovery in large scale systems. Unfortunately, some large sewage treatment works possess anaerobic digestion systems, but do not run them efficiently due to both economic and technological difficulties. Sludge treatment systems were even simply removed from designs of some recently built sewage treatment works.

To alleviate the load for sewage sludge treatment, composting has been regarded as a suitable technology for sludge stabilization especially in wastewater treatment plants of small or medium scale in China. Modern composting technology was initially developed for treatment of municipal solid wastes in this country about 15 years ago [30]. Later, sewage sludge was added to the raw materials to increase organic matter and plant nutrient contents and to adjust humidity, which is also a way to treat and dispose sludge itself $[31,32]$. Aerated-pile systems have been adopted for sewage sludge composting due to its relatively low cost and high efficiency. For this technology, municipal solid wastes, crop stems, sawdust or some other organic wastes are usually added to reduce the water content and to improve the aeration condition of sewage sludge. Some systems were also developed using mechanical turning and forced aeration to compost the sewage sludge without humidity adjusters. However, few composting systems are running normally in China because of technological and economic difficulties. People hope that composting plants could support themselves by sale of the compost products, but compared to the low price of compost, transportation is too expensive. To increase 


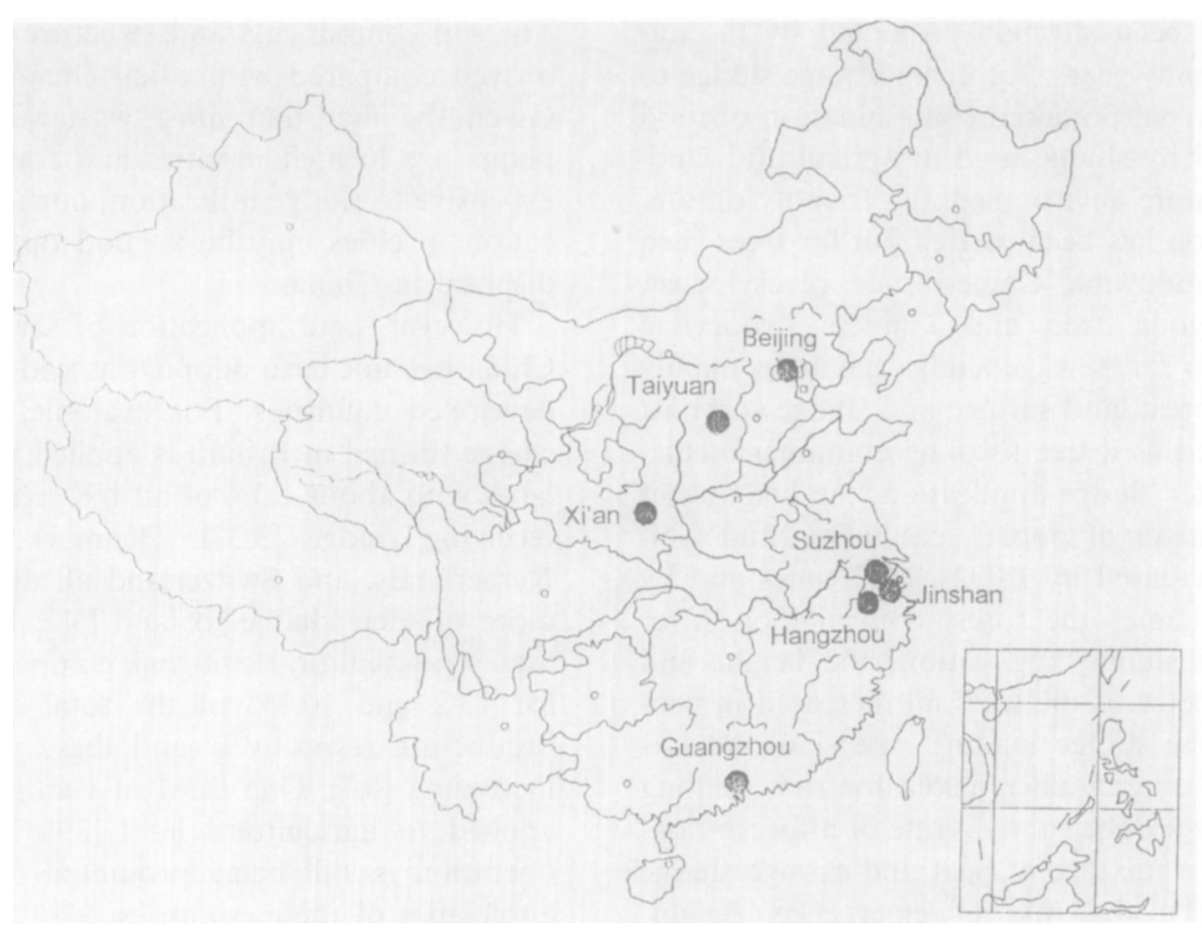

Fig. 1. The seven Chinese cities where the 12 wastewater treatment plants are located.

the price of compost products, an effort was made to producc combined fertilizers using sewage sludge and some chemical fertilizers. Such combined fertilizers possess both high plant nutrient contents and high organic matter ratio and are proposed to be potential substitutes for the currently widely used chemical fertilizers which usually result in declining of soil quality.

In China, most activities of sewage sludge land use have been focused on agricultural fields, especially the fields around wastewater treatment plants [28]. This operation involves nearly all kinds of main crops in China, i.e. rice, wheat, corn, millet, soybean, rye, taro, Chinese cabbage, cucumber, tomato, lettuce, hot pepper, cauliflower, and cabbage $[10-12,16-18,28,31,32]$. Application of 37.5 tons per hectare of sewage sludge compost increased the yield of wheat by $54.1 \%$ and the Chinese cabbage by $120 \%$, compared with control fields [31]. The protein content of the wheat increased by $14 \%$. For millet and corn, applications of 45,60 and 75 tons per hectare of sewage sludge gave yields respectively similar to those produced by the fields applied with agricultural organic fertilizers [17]. Yields of taro and tomato in sludge amended soil were higher than for control soils by $47-62$ and $11 \%$, respectively [9]. Sewage sludge was also applied with chemical fertilizers together to field, giving higher yield of Chinese cabbage than a field which only received sludge [18]. Lettuce in soil amended with 10\% of sewage sludge could grow more quickly than the control [11]. Soil amended with sludge produced similar a yield of rice to that applied with chemical fertilizers, but kept organic matter and plant nutrient contents higher for the next crop [13]. Organic matter and plant nutrient contents of soil are increased by application of sewage sludge even more than by livestock manure [12,32]. Soil water/air-holding capacities, soil bulk density, total microorganism population and structure, percent total aggregates and percent water-stable aggregates are all improved by sludge application [12,32].

Forest coverage rate in China has been increasing from $9 \%$ in 1949 to $13.92 \%$ in 1994 , which is still much lower than the world average of $32 \%$ [33]. Therefore ecological engineering of the forest 
industry has been strongly promoted by the authority for many years. Applying sewage sludge to forests can avoid potential contamination of food chain caused by sludge used in agricultural land, implying a more environmentally friendly option. This operation has been carried out for trees such as poplar, paulownia, Chinese pine, black locust. Chinese pagoda tree and Chinese arborvitae $[19,34,35]$. So far, sewage sludge has been mainly applied to forest land surface and sludge compost has been used as a tree seedling container media. One year after sludge application, the height and ground diameter of poplar, paulownia and Chinese pine increased by $1.092-1.412$ times and by 1.056-1.208 times the forest control [36]. After 1.5 years of sludge application, the height and ground diameter of the trees all increased in proportion to the sludge loading rates [36]. Peat is usually used as container media for tree seedling culture to ensure the survival rate of afforestation. When using a mixture of peat and sewage sludge compost (1:1), the rate of emergence, height, ground diameter and biomass (dry weight) were all significantly higher than those grown in peat only [34]. After 1 year of application, total nitrogen, available nitrogen, total phosphorus, organic matter content and cation exchange capacity (CEC) in the forest surface soil $(0-20 \mathrm{~cm})$ amended with sewage sludge were all significantly higher than the soils with no application or with chemical fertilizers. The bulk density, water-holding capacity and porosity of the sludge amended forest soil were also improved [36].

Along with the rapid economic development, cities in China have been developing quickly. Modern cities should be made green and beautiful by planting trees, lawn and flowers. To serve horticulture in China, sludge compost has been also used for ornamental plants such as the rose of Sharon, Chinese rose, Chinese hibiscus, evergreen euonymus, kumquat, five-leaf humid euphorbia, nasturtium, canna, common cineraria, ryegrass, red fescue, bentgrass, buffalo grass, white clover and Manila grass [35]. Growing in the soil applied with sludge compost, flowers blossom more and keep longer, the biomass of grasses is higher and the lawn keeps green longer, compared to the control with no sludge amendment.
The soil components and structure were also improved compared with using chemical fertilizers. Given the fact that most wastewater treatment plants are located in cities and transportation is expensive to sludge utilization, horticultural application in cities may be a good option of sludge disposal in China.

However, land application of sewage sludge in China has not been adopted as widely as in some developed countries. For example, over $50 \%$ of sludge formed in Britain is applied to agricultural land, with about $1.3 \%$ of all UK agricultural land receiving sludge [3,37]. Denmark, France, the Netherlands, and Switzerland all dispose $30 \%$ or more of their sludge to land [38]. In the United States, agricultural use and composting account for 13.2 and $10.1 \%$ of the total sewage sludge production respectively and these ratios are still increasing $[6,7]$. One third of Canadian sludge is applied to agricultural land [39]. Even so, this operation is still being promoted further by the authorities of these countries [3].

\section{Pollution control of sewage sludge land application}

During wastewater treatment processes, some harmful chemicals and pathogens can become concentrated in sewage sludge. Tables 3 and 4 list some heavy metals and harmful elements in China and some other countries' sewage sludges. Zinc is usually the highest among the heavy metals in sewage sludge. The concentrations of the inorganic pollutants in Chinese sewage sludges are generally lower than those from the countries listed in Table 4. Heavy metals in sewage sludge cannot be removed by common sludge treatment technologies and will return to the environment again when sludge is applied to the land. Organic pollutants in sewage sludge have been studied for many years in some other countries $[3,41,42]$, but in China little work has been done in this area. As merely a supplementary work to wastewater analysis, some azotic-aromatic compounds in sewage sludge from Beijing Gaobeidian sewage treatment plant were measured [43]. A total of 35 azotic aromatic compounds were identified and seven 
Table 3

Inorganic pollutants in China's sewage sludges $(\mathrm{mg} / \mathrm{kg})$

\begin{tabular}{|c|c|c|c|c|c|c|c|c|c|}
\hline Sewage treatment plant & $Z n$ & Cu & $\mathrm{Ni}$ & $\mathrm{Hg}$ & As & $\mathrm{Cd}$ & $\mathrm{Pb}$ & $\mathrm{Cr}$ & B \\
\hline Guangzhou Datansha [9.11] & 3394 & 1225 & 693.1 & 1.96 & 57.12 & 2.56 & 150.0 & 1550 & - \\
\hline Suzhou Chengxi [40] & 1739 & 88.7 & 10.4 & - & - & 1.3 & 61.6 & ..- & - \\
\hline Xian $[14]$ & 2803 & 605.8 & 266 & 2.37 & 23.8 & 1.30 & 374 & 1423 & \\
\hline Taiyuan Yangjiabao [17] & 775.1 & 149.2 & 39.1 & 6.96 & 19.8 & 0.95 & 54.5 & 42.6 & 51.3 \\
\hline Taiyuan Beijiao [17] & 1525 & 222.6 & 32.4 & 6.43 & 15.5 & 0.65 & 49.8 & 271.1 & 59.2 \\
\hline Taiyuan Yinjiabao [17] & 1423 & 3068 & 297.1 & 6.40 & 23.3 & 4.30 & 53.3 & 1411 & 51.2 \\
\hline Taiyuan Zhenchengdi [17] & 168.6 & 39.3 & 27.3 & 0.68 & 5.60 & -- & 66.6 & 4.3 .9 & - \\
\hline Taiyuan Gujiao [17] & 261.2 & 28.4 & 32.9 & 0.61 & 9.18 & 0.05 & 42.3 & 49.1 & - \\
\hline Hangzhou Sibao [8] & 4205 & 367.1 & 467.6 & 1.86 & 12.95 & 3.55 & 135.5 & 537.2 & -. \\
\hline Iinshan Shihua $[8]$ & 8352 & 193.0 & 53 & 2.50 & 7.50 & 2.40 & 371 & 249 & - \\
\hline Beijing Jiuxianqiao $[18,19]$ & 64.0 & 35.2 & - & $\ldots$ & - & - & - & $\ldots$ & - \\
\hline Beijing Gaobeidian $[16,19]$ & - & - - & - & - & - & -. & 41.0 & $\ldots-$ & - \\
\hline Median & 1525 & 193 & 46.1 & 2.37 & 15.5 & 1.30 & 61.6 & 271 & 51.3 \\
\hline Mean & 2246 & 548 & 192 & 3.31 & 19.4 & 1.90 & 127 & 620 & 53.9 \\
\hline $\pm S D$ & \pm 2437 & \pm 908 & \pm 235 & \pm 2.56 & \pm 15.6 & \pm 1.40 & \pm 127 & \pm 651 & \pm 4.59 \\
\hline
\end{tabular}

-.' represents unavailable data.

were quantitatively determined. The quantitative results are in Table 5. For the comparative purpose, the distribution of median dry matter concentrations of organic pollutants found in sewage sludges produced in the USA and some European countries is given in Table 6 , including 11 groups of 120 compounds [42]. However, little work on organic contaminants in China sludge does not necessarily mean that few organic pollutants exist in China sewage sludge. It was reported that the coli titre of Suzhou Chengxi sewage sludge is $1.42 \times 10^{-5}[40]$. In the same sludge, roundworm eggs were $5 / \mathrm{ml} .50 .3 \%$ of which were dead.

Harmful chemicals and pathogens in sewage sludge may potentially get into other environmental media to which humans may be exposed. However, so far studies in China provide different opinions to the question whether or not land application of sewage sludge could result in harmful environmental contamination or exposure to people.

Many research projects resulted in a positive answer. Guo and coworkers [44] reported that heavy metals in sludge did not accumulate in plants highly, and the concentrations of $\mathrm{Hg}$, As, $\mathrm{Pb}, \mathrm{Cr}$ and $\mathrm{Cd}$ in edible parts of corn, millet and Chinese cabbage did not reach China's national hygienic standards for food when a poor soil was applied with 75 ton/ha of sludge or 240 ton/ha of a compost of a mixture of sludge and municipal solid wastes (1:1). They also found that heavy metal concentrations in poor soil did not reach the background values plus twice their S.D. with the same applications, indicating no threat to the soil quality [32]. Zhong et al. reported that concentrations of $\mathrm{Ni}$ in taro and tomato growing in the sandy soil with sludge loads of 15 and 30 ton/ha were 1.9 times and 1.5 times as those of the control samples respectively, but still lower than safety limit [9]. They predicted that sludge application in the sandy soil could be carried out safely and continuously for 12 years with a load of 15 ton/ha per year [9]. Zhang and Xue found that after 1 year of surface application of sludge at rates of 22.5-67.5 ton/ha, concentration of nitrate radicals in a drab soil declined along with the soil depth and was less than $30 \mathrm{mg} / \mathrm{kg}$ at the depth of $100-120 \mathrm{~cm}$ below, indicating that groundwater was not contaminated [36]. Concentrations of $\mathrm{Cd}, \mathrm{Cu}, \mathrm{Cr}, \mathrm{Zn}$ and $\mathrm{Pb}$ in the poor soil at the depth of $20-40$ and $50-70 \mathrm{~cm}$ did not increase compared to the control, showing that the metals in soil did not move downward. Based on experiments with $120 \mathrm{~cm}$ high packed columns, Zhou et al. [13] pointed out that leaching of nitrate radicals in sludge-amended soil was far less 
Table 4

Median concentrations of inorganic pollutants in sewage sludges in some other countries ( $\mathrm{mg} / \mathrm{kg}$ )

\begin{tabular}{|c|c|c|c|c|c|c|c|c|c|c|c|c|c|}
\hline & \multicolumn{3}{|c|}{ UK $[20]$} & \multicolumn{3}{|c|}{ US [20] } & \multirow[t]{2}{*}{ Sweden $[20]$} & \multicolumn{4}{|c|}{$\operatorname{RSA}[21]$} & \multirow[t]{2}{*}{ Median } & \multirow[t]{2}{*}{ Mean \pm S.D } \\
\hline & 1 & 2 & 3 & 1 & 2 & 3 & & 1 & 2 & 3 & 4 & & \\
\hline $\mathrm{Zn}$ & 2847 & 3000 & 1270 & 2200 & 1480 & 1890 & 1570 & 1327 & 1886 & 1517 & 1025 & 1570 & $1819 \pm 636$ \\
\hline $\mathrm{Cu}$ & 1121 & 800 & 546 & 700 & 1200 & 1000 & 560 & 212 & 352 & 298 & 381 & 560 & $652 \pm 342$ \\
\hline $\mathrm{Ni}$ & 201 & 80 & 94 & 52 & 169 & 85 & 51 & 44 & 93 & 80 & 37 & 80 & $89.6 \pm 51.7$ \\
\hline $\mathrm{Cd}$ & 107 & 12 & 17 & 12 & 64 & 16 & 6.7 & 3.0 & 6 & 4 & 3 & 12 & $22.8 \pm 32.8$ \\
\hline $\mathrm{Pb}$ & 900 & 700 & 324 & 480 & 1450 & 540 & 180 & 166 & 299 & 213 & 198 & 324 & $496 \pm 395$ \\
\hline $\mathrm{Cr}$ & 887 & 250 & 335 & 380 & 1260 & 1350 & 86 & 71 & 506 & 177 & 117 & 335 & $493 \pm 465$ \\
\hline Mn & 397 & 400 & - & - & 143 & 280 & 384 & - & -- & - & - & 384 & $321 \pm 111$ \\
\hline Mo & 7.7 & 5 & - & - & 8.1 & 30 & - & - & - & - & - & 7.9 & $12.7 \pm 11.6$ \\
\hline $\mathrm{Co}$ & 16.5 & 12 & 13.7 & - & 8.8 & 7.0 & 10.8 & - & - & - & - & 11.4 & $11.5 \pm 3.4$ \\
\hline
\end{tabular}

‘- represents unavailable data.

than that in soil applied with chemical fertilizers. Zhang reported that concentrations of total nitrogen and total phosphorus in surface runoff were all too low to contaminate downstream water body when sludge load was less than 90 ton/ha and slope of grass land was less than 0.10 [35].

Some suggested, however, that the issue of sludge land application should be taken very carefully. While believing edible parts of rice, wheat, Chinese cabbage, hot pepper and cabbage would not be contaminated by heavy metals in sludge applied at a load of 15 ton/ha for vegetable field or 10 ton/ha for rice or wheat field, Zhou et al. [40] pointed out that zinc accumulated in sludgeamended soil significantly and moved downward to a depth of $60 \mathrm{~cm}$ in vegetable field and to 40

Table 5

Azotic-aromatic compounds in Beijing Gaobeidian sludge [43]

\begin{tabular}{ll}
\hline Compound & Concentration (ppb) \\
\hline Quinoline & $24.6-28.2$ \\
Isoquinoline & $19.8-246.5$ \\
2-Methyl quinoline & $32.7-591.1$ \\
8-Methyl quinoline & $11.3-92.7$ \\
Benzo-(h)-quinoline & $23.4-189.4$ \\
Acridine & $14.2-295.9$ \\
Benzo-(f)-quinoline & 15.499 .1 \\
\hline
\end{tabular}

$\mathrm{cm}$ in rice or wheat field. They also emphasized that sewage sludge should be sterilized/stabilized before land application because of its high content of pathogens. Yang and Wang found that lead can be strongly accumulated by both soybean and rice [16]. A study on a field which had received sludge for more than 10 years showed that soil concentrations of $\mathrm{Hg}$ and $\mathrm{Cd}$ increased significantly with the history of sludge application [28]. Wheat and corn growing in soil with loads of $37.5-75 \mathrm{~m}^{3} / \mathrm{ha}$ of sludge were all polluted by $\mathrm{Hg}$ and $\mathrm{Cd}$. Wheat was contaminated more than corn, and $\mathrm{Cd}$ concentrations were higher than $\mathrm{Hg}$. Vegetables were not polluted by $\mathrm{Cd}$ and $\mathrm{Hg}$. The concentration of zinc in lettuce growing in sludge amended soil could be higher than the safety limit [11].

These different opinions have resulted from experiments carried out under different conditions such as different soils, different weather, different plants and different working methodologies. This also indicated that land application of sewage sludge in a large country like China can be a very complicated issue. Obviously, more detailed work, especially field work, needs to be done before the correct answer can be finally obtained.

'Control Standards for Pollutants in Sludges from Agricultural Use' was issued in 1984 and 
Table 6

Distribution of median dry matter concentrations of organic pollutants in sewage sludges produced in the US and European countries [42]

\begin{tabular}{|c|c|c|c|c|c|c|}
\hline \multirow[t]{2}{*}{ Chemical group } & \multirow[t]{2}{*}{$\begin{array}{l}\text { No. of organic chemicals } \\
\text { tested }\end{array}$} & \multicolumn{5}{|c|}{$\begin{array}{l}\text { No. of organic chemicals tested having median con- } \\
\text { centrations in sludges }(\mathrm{mg} / \mathrm{kg} \text {, dry wt. basis) }\end{array}$} \\
\hline & & ND & $<\mathrm{l}$ & $1-10$ & $11-100$ & $>1000$ \\
\hline Phthalate esters & 6 & 0 & 0 & 1 & 4 & 1 \\
\hline Monocyclic aromatics & 23 & 12 & 5 & 2 & 4 & 0 \\
\hline Polynuclear aromatics (PAH) & 7 & 0 & 4 & 2 & 1 & 0 \\
\hline Halogenated biphenyls & 9 & 1 & 3 & 5 & 0 & 0 \\
\hline Dioxins and furans & 11 & \multicolumn{5}{|c|}{ (all significantly $<1 \mathrm{mg} / \mathrm{kg}$ ) } \\
\hline Halogenated aliphatics & 10 & 0 & 6 & 4 & 0 & 0 \\
\hline Triaryl phosphate esters & 3 & 0 & 0 & 2 & 1 & 0 \\
\hline Aromatic and alkyl amines & 16 & 6 & 9 & 0 & 1 & 0 \\
\hline Phenols & 12 & 0 & 1 & 11 & 0 & 0 \\
\hline Chlorinated pesticides and hydrocarbons & 21 & 4 & 14 & 3 & 0 & 0 \\
\hline Miscellaneous compounds & 2 & 1 & 0 & 1 & 0 & 0 \\
\hline Totals & 120 & 24 & 42 & 31 & 11 & 1 \\
\hline
\end{tabular}

enforced in 1985 [45]. The maximum permitted contents of some pollutants in sludge are listed in Table 7. Besides the content limits in Table 7, the standard also has a series of items stipulating: load of sludge application should not be in excess of 30 ton/ha; sludge application in a field should not be carried out for more than 20 years if any of the inorganic chemicals in Table 7 is near to the limit value; sludge should not be used to sandy

Table 7

Control standard for pollutants in sludges for agricultural use $(\mathrm{mg} / \mathrm{kg}$, dry weight)

\begin{tabular}{lrr}
\hline Chemical & Maximum Permitted Content \\
\cline { 2 - 3 } & Soil pH value & \\
& $<6.5$ & $\geq 6.5$ \\
\hline $\mathrm{Cd}$ & 5 & 20 \\
$\mathrm{Hg}$ & 5 & 15 \\
$\mathrm{~Pb}$ & 300 & 1000 \\
$\mathrm{Cr}$ & 600 & 1000 \\
$\mathrm{As}$ & 75 & 75 \\
$\mathrm{~B}$ & 150 & 150 \\
$\mathrm{Mineral}$ oil & 3000 & 3000 \\
$\mathrm{Benzo}$ atpyrenc & 3 & 3 \\
$\mathrm{Cu}$ & 250 & 500 \\
$\mathrm{Zn}$ & 500 & 1000 \\
$\mathrm{Ni}$ & 100 & 200
\end{tabular}

soil, land with high ground water level or conservational area for water resources; sludge must be composted or digested before land application; sludge should not be used on vegetable field or grass land used for grazing within 1 year; acid soil should be amended with lime besides a adhering to the limits for sludge load; sludge load should be reduced if contents of more than 1 chemicals in sludge near to the limits; if crop growth is affected negatively or harmful chemical content in crop excesses any relative standard, sludge application should be stopped and some action should be taken to rescue the land. There has been no regulations for pathogen control of sludge land application. 'Sanitary Standard for the Non-hazardous Treatment of Night Soil' issued in 1987 was often used for sludge composting [46] and discharge standard of hospital sewage sludge in the 'Discharge Standards of Hospital Wastewater' issued in 1983 was adopted by some authors to assess sludge quality [47].

\section{Problems and conclusions}

\subsection{Sewage sludge quality}

The quality of many China's sewage sludges is lower than the requirement by the control stan- 
dards. Heavy metals and persistent organic pollutants are main factors affecting sludge quality. For example, more than half of the sludges listed in Table 3 have one or more chemicals in excess of the maximum permitted content given in Table 7. Improving sewage sludge quality is one of the key points for pollution control of sludge land application. However, sludge quality results from the quality of wastewater received by sewage treatment plant. Therefore, more efforts should be made to ensure the wastewater quality by enforcing all the discharge standards for industrial wastewaters strictly.

\subsection{Sludge treatment/stabilization}

Although it is stipulated in the standard that sewage sludge should be composted or digested before land application, most land used sludge in China has not been treated properly so far. The national standard should be enforced rigorously by establishing effective monitoring and inspecting systems for sludge treatment and land utilization. Meanwhile, development and spread of sludge treatment technologies suitable to Chinese conditions should be paid more attention. Composting should be promoted for the large number of sewage treatment plants with small or middle scale and all the large wastewater treatment works must set up and run anaerobic digestion systems for sludge trreatment.

\subsection{Promoting beneficial use}

There may be quite a lot different ways to reuse sludge, but currently land use is the most important. Land application of sewage sludge will account for more and more of the portion of sludge produced in China. However, few modern technologies for sludge land utilization have been developed in China and therefore sludge has been applied to land casually, resulting in environmental pollution. China is a large country with different soils and a wide range of weathers in different places suitable for different plants. Various technologies may be needed for each specific circumstances to increase crop yield and to avoid pollution to the environment and exposure to the human. Sludge users should be trained with proper technologies to apply sludge in environmentally friendly ways.

\subsection{Improvement and enforcement of legislation}

In China, the current control standard for pollutants in sludges for agricultural use was established only based on work for wheat [16]. Obviously, more typical crops in different conditions should be studied for the control standard. Limit for some metals may need changing as Yang and Wang have suggested [16]. Control standard for pathogens in sewage sludge should also be established for land application. After all, all the standards should be enforced rigidly.

\subsection{National survey}

A national survey should be carried out to investigate sewage sludge production and components including all the main inorganic and organic pollutants existing in sludges statewidely. This survey will give a clear picture of the general situation of China's sewage sludge and lay the basis for management and utilization at the national level.

\subsection{Research needed}

All the legislation and management should be based on the results from scientific research. Little work on organic pollutants in China's sewage sludge has been done. Therefore research work in this area should be encouraged to study the occurrence of organic pollutants in China's sewage sludges and their behavior and fate during sludge treatment processes and in soil-plant systems after applied into land with sludge. Work in this field will be very helpful in understanding the important debate of whether or not organic pollutants in sewage sludge could pollute the environment and become exposed to humans. 


\section{Acknowledgements}

The author is grateful to the Working Foundation for Selected Scholars Back from Overseas set by the Chinese Academy of Sciences, the Research Foundation for Scholars Back from Overseas set by the State Education Commission and the Foundation for Scientific and Technological Activity of Scholars Back from Overseas in Noneducational Organizations set by the Personnel Department for their financial support.

\section{References}

[1] Edition Commission, Zhongguo Huanjing Nianjian Press, Zhongguo Huanjing Nianjian, Beijing, 1995.

[2] Science and Technology Bureau of the Construction Department, China 2000 strategy for the sustainable development of water industry, Geishui Paishui, 5 (1995) $31-35$.

[3] Wang, M.-J. and K.C. Jones, Behavior and fate of chlorobenzenes (CBs) introduced into soil-plant systems by sewage sludge application: a review. Chemosphere, 28 (1994) 1325-1360.

[4] Wang, M.-J. and K.C. Jones, Uptake of chlorobenzenes by carrots from spiked and sewage sludge-amended soil. Environ. Sci. Technol., 28 (1994) 1260-1267.

[5] Bruce, A.M. and R.D. Davis, Sewage sludge disposal: current and future options. Water Sci. Tech., 21 (1989) $1113-1128$.

[6] Anon, The sludge dilemma. Operations Forum, 4 (1989) 15-16.

[7] USEPA, A Plain English Guide to the EPA Part 503 Biosolids Rule, EPA/832/R-93/003, 1994.

[8] Xu, Y., Agricultural application of sewage sludge and its environmental impact. Rural Eco-Environ., 3 (1993) 32 35.

[9] Zhong, X.-G., Y. Lin, C.-R. Zhang and Q.-T. Wu, Preliminary study of ecological effects of sewage sludge on agricultural soil. Trop. Subtrop. Soil Sci., 1(2) (1992) $91-97$.

[10] Goldstein, N., EPA tackles sludge rule comments. BioCycle 9 (1989) $56-59$.

[11] Liao, Z.-W., W.-H. Wang, D.-R. Jiang and W.-X. Ou, Heavy metal content of lettuce growing in a material containing sewage sludge. Environ. Sci. (Huanjing Kexue), 15(2) (1994) 49-52.

[12] Zhou, L.-X., J.-T. Hu and N.-F. Ge, Effect on soil fertility of sewage sludge agricultural application. Chin. $J$. Soil Sci., 25(3) (1994) $126-129$.

[13] Zhou, L.-X., Z.-M. Hu and J.-T. Hu, Availability and environmental behavior of nitrogen and phosphorus in raw sewage sludge. Rural Eco-Environ., I1(4) (1995) 1922,56 .
[14] Xiao, L. and X.-Q. Wang, Monthly component change and agricultural utilization of sewage sludge produced in Xi'an sewage treatment plant. Environ. J., 9(2) (1993) $36-39$.

[15] Wang, P.-X., Speciation and its transfer of copper and nickel in soil amended with sewage sludge. Agro-environ. Protect., 12(1) (1993) 13-16.

[16] Yang, Z.-Y. and H.-K. Wang, Study of crop lead pollution by sewage sludge application, Environ. Sci. (Huanjing Kexue), 14(6) (1993) 8-11, 37.

[17] Guo, M.-L., K. Wang, Q.-X. Zhang, Y.-P. Zhang, Y.-Q. Wang, R.-F. Mi, R.-T. Tian, X.-L. Wang and M.-Q. Xi, Study of agricultural utilization of sewage sludge in Taiyuan. Agro-environ. Protect., 12(6) (1993) 258-262, 285.

[18] Liu, S.-J., J.-M. Xu and Y.-X. Li, Study of sewage sludge application to land for Chinese cabbage. Beijing Agric. Sci., 12(6) (1994) 22-24.

[19] Zhang, T.-H., Studies on the Sludge Application to Forest Land, MSc dissertation, Northwestern Agricultural University, Yangling, Shanxi, 1992.

[20] McGrath, S.P., Metal concentrations in sludges and soil from a long-term field trial. J. Agric. Sci.. Camb., 103 (1994) 25-35.

[21] Korentajer, A review of the agricultural use of sewage sludge: benefits and potential hazards. Water SA, 17 (1991) 189-196.

[22] Strachan, G.W., D.W. Nelson and L.E. Sommers, Sewage sludge components extractable with non-aqueous solvents. J. Environ. Qual., 12(1) (1983) 69-74.

[23] Peterson, A.E., P.E. Speth and P. Schlecht, Effect of sewage sludge application on groundwater quality, in The 11 th Annual Madison Waste Conference-Municipal and Industrial Waste, University of Wisconsin-Madison, Madison, WI, 1988, pp. 272-285.

[24] Barnhisel, R.I., M.D. Ellis and T.A. Fauerbacher, Utilization of municipal sewage sludge as a spoil amendment in the reclamation of lands surface mined for coal, in G.H. Graves (Ed.), Symp. Surface Mining Hydrology, Sedimentology, and Reclamation, University of Kentucky, Lexington, KY, 1980, pp. 187-192.

[25] Griebel, G.E.. W.H. Armiger, J.F. Parr, D.W. Steck and J.A. Adam, Use of composted sewage sludge in revegetation of surface mined areas, in W.E. Sopper and S.N. Kerr (Ed.), Utilization of Municipal Sewage Sludge Effluent and Sludge on Forest and Disturbed Lands. The Pennsylvania State University Press, University Park, 1979, pp. 293-303.

[26] Kerr, S.N. and W.E. Sopper, One alternative to ocean disposal of sludge: recycling through land reclamation, in W.E. Sopper et al. (Eds.), Land Reclamation and Biomass Production with Municipal Wastewater and sludge. The Pennsylvania State University Press, University Park, 1982, pp. 105-117.

[27] Stucky, D.J. and J. Bauer, Establishment, yield and ion accumulation of several forage species on sludge-treated spoils of the Palzo mine, in W.E. Sopper and S.N. Kerr 
(Eds.). Utilization of Municipa! Sewage Sludge Effluent and Sludge on Forest and Disturbed Lands, The Pennsylvania State University Press, University Park, 1979, pp. $379-387$.

[28] Ouyang. X.-H.. J. Cui, and Q. Dong, Effects on agricultural soil and crops of long term application of sewage sludge. Agro-environ. Protect., 13(6) (1994) 271-274.

[29] USEPA, Land Application of Municipal Sludge, EPA625/1-83-016, 1983.

[30] Chen, S.-H., Review of composting technologies for municipal refuse in China. Environ. Sci. (Huanjing Kexue), 15(1) (1993) $53-56$.

[31] National Environmental Protection Agency, Study on Municipal Wastewater Reuse. Science Press, Beijing. 1992.

[32] Guo, M.-L., R.-F. Mi, R.-T. Tian, M.-Q. Xi and X.-L. Wang, Effects of city sewage sludge and sludge waste compose on the soil as a fertilizer resource. Agro-environ. Protect, 13(5) (1994) 204-209.

[33] Editorial Board, China Environment, Environmental and Resources Protection Committee of National People's Congress, Beijing, 1995.

[34] Li, Y.X. Studies on the Application of Sludge and Refuse Compost as Tree Seedling Container Media, MSc dissertation, Northwestern Agricultural University, Yangling, Shaanxi, 1995.

[35] Zhang, Z.-Q., Studies on the Application of Sludge Compost to City Gardens and Turfgrass Lands, MSc dissertation, Northwestern Agricultural University, Yangling, Shaanxi, 1994.

[36] Zhang, T.-H. and C.-Z. Xue, The effects of Xi'an sewage sludge applied to the forest lands. Acta Univ. Agric. Boreali-occidentalis, 22(2) (1994) 67-71.

[37] Beck, A.J., R.E. Alcock, S.C. Wilson, M.-J. Wang, S.R. Wild, A.P. Sewart and K.C. Jones, Long-term persistence of organic chemicals in sewage sludge-amended agricultural land: a soil quality perspective. Adv. Agron., 55 (1995) 345-391.
[38] Sauerbeck, D, Effects of agricultural practices on the physical, chemical and biological properties of soils: part II--use of sewage sludge and agricultural wastes, in H. Barth, P.L. Hermite (Eds.), Scientific Basis for Soil Protection in the European Community. Elsevier. London, 1987, pp. $181-210$.

[39] Webber, M.D. H.R. Rogers, C.D. Watts. A.B.A. Boxall, R.D. Davis and R. Scoffin, Monitoring and prioritization of organic contaminants in sewage sludges using specific chemical analysis and predictive, non-analytical methods. Sci. Total Environ., 185 (1996) 27-44.

[40] Zhou, L.-X.. J.-T. Hu and N.-F. Ge, Impact on crop and soil of Zinc and pathogens in sewage sludge. Agro-environ. Protect.. 13, (4) 158-162 (1994).

[41] Jones, K.C., Introduction. Sci. Total Environ.. 185 (1996).

[42] Jacobs, L.W., G.A. O'Connor, M.A. Overcash, M.J. Zabik, and P. Rygiewicz, Effects of trace organics in sewage sludges on soil-plant systems and assessing their risk to humans, in A.L. Page, T.J. Logan and J.A. Ryan (Eds.), Land Application of Sludge Food Chain Implications, Lewis, MI, 1987, pp. 101-143.

[43] Ke, J.-M. and S.-H. Lei, A preliminary study on the analysis of toxic organic pollutants in Gaobeidian sewage treatment system of Beijing, in Advances in Environmental Protection Science and Technology, (Beijing Institute of Environmental Science and Technology, Ed.), China Construction Press, Beijing, 1993, pp. 225-227.

[44] Guo, M.-L., R.-T. Tian, Y.-Q. Wang, Q.-X. Zhang and X.-H. Zhao, Crop accumulation of heavy metals from soil amended with municipal refuse and sewage sludge. Agroenviron. Protect., 14(2) (1995) 67-71.

[45] Department of Rural and Urban Construction and Environmental Protection, Control Standards for Pollutants in Sludges from Agricultural Use, GB 4284-84, 1984.

[46] Health Department, Discharge Standard of Manure, GB 7959-87. 1987.

[47] Health Department, Discharge Standard of Hospital Wastewater, GBJ-48-83, 1983. 